\title{
RHEUMATOID FACTOR, COMPLEMENT, AND CONGLUTININ ABERRATIONS IN PATIENTS WITH SUBACUTE BACTERIAL ENDOCARDITIS *
}

\author{
By RALPH C. WILLIAMS, JR. AND HENRY G. KUNKEL
}

(From The Rockefeller Institute, New York, N. Y.) ․

(Submitted for publication September 28, 1961 ; accepted October 30, 1961)

Subacute bacterial endocarditis produces in man a complex situation of interaction of host and invading organism. Little is known of antibody response or of the specific mechanisms of immunity involved during the inception, course, and recovery from subacute bacterial endocarditis, although observations on streptococcal agglutinating and complement-fixing antibodies have been made by numerous workers (1-7). Recent observations $(8,9)$ have indicated that animals immunized with certain streptococcal and coliform organisms develop factors capable of agglutinating $\gamma$-globulin-coated red cells and other particles. These properties indicate a similarity to rheumatoid factors, and the possibility is raised that organisms or their products play a role in the production of rheumatoid factors in human disease. A natural parallel to production of such rheumatoid factors in animals would be their occurrence in human disease states in which bacteria are constantly fed into the circulation, as in miliary tuberculosis or subacute bacterial endocarditis.

In the present study the effect of subacute bacterial endocarditis on the serological behavior of systems designed to react with the rheumatoid factor was examined. Preliminary observations indicated a high incidence of positive tests for rheumatoid factor in these patients. It seemed of special interest to see whether these reversed after eradication of the offending organism under therapy. The constancy and prolonged duration of these factors in patients with rheumatoid arthritis is well recognized $(10,11)$ although some observers have reported decrease in titer with remission (12). In addition, observations were also made on conglutinin and serum complement in these patients because of certain general similarities of these various factors that appear to be indirectly involved in immune phenomena.

\footnotetext{
* Aided by a grant from The National Foundation.
}

\section{METHODS AND MATERIALS}

Sera were collected from 51 patients with subacute bacterial endocarditis; 41 had the diagnosis of bacterial endocarditis supported by at least two positive blood cultures. Autopsy confirmed the diagnosis in 3 patients. The remaining 10 had negative blood cultures but showed varying degrees of persistent fever, anemia, splenomegaly, microscopic hematuria, and embolic phenomena sufficient for a presumed diagnosis of bacterial endocarditis.

Latex fixation tests and sensitized sheep cell tests were performed on serially drawn sera using methods previously described $(13,14)$. " In addition, capillary tube precipitation of bacterial endocarditis sera with aggregated $\gamma$-globulin was performed (15). Precipitin curves with both plain serum and serum heated to $56^{\circ} \mathrm{C}$ for 30 minutes were determined by using aggregated $\boldsymbol{\gamma}$-globulin as antigen (16). The difference between precipitin curves of plain and heated serum was taken to indicate the relative contributions of complement components to the precipitate material. The height of the curves with serum previously heated to $56^{\circ} \mathrm{C}$ for 30 minutes was indicative of the reaction between pure aggregates and rheumatoid factors.

Many of the sera from bacterial endocarditis patients were tested for direct agglutination by use of group $O$ $\mathrm{Rh}$ positive red cells coated with incomplete anti-Rhantibody.

Serum complement determinations were performed by the modified method of Mayer, Eaton and Heidelberger as described by Fischel, Pauli and Lesh $(17,18)$. Immunoconglutinin was determined by the method of Coombs and Coombs (19).

Starch block electrophoresis and sucrose density gradient ultracentrifugation were performed with methods previously described from this laboratory $(20,21)$.

\section{RESULTS}

Measurement of rheumatoid factors. Positive latex fixation tests were present in 26 of the 51 sera (50 per cent). Ten, or 19 per cent, of these sera from patients with bacterial endocarditis exhibited varying degrees of reactivity with sensitized sheep cells (Table I). There 
TABLE I

Clinical findings and serological results in the different patients with endocarditis*

\begin{tabular}{|c|c|c|c|c|c|c|c|c|}
\hline $\begin{array}{l}\text { Patient } \\
\text { Sex Age }\end{array}$ & Blood culture & $\begin{array}{l}\text { Type of heart } \\
\text { disease }\end{array}$ & $\begin{array}{l}\text { Latex fixat } \\
\text { Date }\end{array}$ & n titer & $\begin{array}{l}\text { Sheep- } \\
\text { cell } \\
\text { titer }\end{array}$ & $\begin{array}{l}\text { Cap. } \\
\text { precip. }\end{array}$ & $\mathrm{C}^{\prime}$ & Conglut. \\
\hline $\begin{array}{l}\text { 1. M.A. } \\
\text { F } 52\end{array}$ & $\alpha$-strep. & Pat. ductus & $\begin{array}{l}4 / 12 / 60 \\
2 / 9 / 61 \\
6 / 3 / 61\end{array}$ & $\begin{array}{c}40,960 \\
0 \\
0\end{array}$ & $\mathbf{0}$ & $\begin{array}{l}4+ \\
0 \\
0\end{array}$ & 51 & 0 \\
\hline 2. $\underset{F}{A} 23$ & $\alpha$-strep. & RHD, MR & $4 / 18 / 60$ & 640 & 0 & $2+$ & & \\
\hline $\begin{array}{l}\text { 3. D.W. } \dagger \\
\text { M } 85\end{array}$ & S. aureus & RHD, MR & $\begin{array}{l}12 / 23 / 60 \\
12 / 29 / 60\end{array}$ & 0 & 0 & $\begin{array}{l}0 \\
0\end{array}$ & 13 & 64 \\
\hline $\begin{array}{l}\text { 4. M.D. } \\
\text { F } 70\end{array}$ & S. aureus & ASHD, MR & $\begin{array}{l}2 / 11 / 61 \\
2 / 24 / 61 \\
3 / 2 / 61 \\
3 / 24 / 61\end{array}$ & $\begin{array}{r}640 \\
160 \\
0\end{array}$ & 0 & $\begin{array}{l}0 \\
0 \\
0 \\
0\end{array}$ & 54 & 2 \\
\hline 5. G.K. & $\alpha$-strep. & RHD, AI, AS & $\begin{array}{l}2 / 17 / 61 \\
3 / 24 / 61 \\
7 / 13 / 61\end{array}$ & $\begin{array}{r}5,120 \\
320 \\
0\end{array}$ & $\mathbf{0}$ & $\begin{array}{l}2+ \\
\pm \\
0\end{array}$ & 45 & 4 \\
\hline 6. J.Mc. & $\alpha$-strep. & RHD, AI, AS & $\begin{array}{l}1 / 6 / 61 \\
1 / 19 / 61\end{array}$ & $\begin{array}{l}320 \\
160\end{array}$ & 0 & $\begin{array}{l}1+ \\
\pm\end{array}$ & 24 & $\begin{array}{l}4 \\
8\end{array}$ \\
\hline 7. $\underset{F}{J} \cdot \mathrm{B}$ & Enterococ. & RHD, AS, AI, & $\begin{array}{l}1 / 5 / 61 \\
1 / 18 / 61\end{array}$ & $\mathbf{0}$ & 0 & $\begin{array}{l}\mathbf{0} \\
\mathbf{0}\end{array}$ & 36 & 8 \\
\hline 8. A.F. & Enterococ. & RHD, AS & $1 / 8 / 61$ & 40 & 40 & $\mathbf{0}$ & 46 & $\mathbf{0}$ \\
\hline $\begin{array}{l}\text { 9. F.Mc.G. } \\
\text { M } 47\end{array}$ & $\alpha$-strep. & RHD, MR & $\begin{array}{l}3 / 30 / 61 \\
4 / 12 / 61 \\
5 / 22 / 61\end{array}$ & $\begin{array}{l}0 \\
0\end{array}$ & $\begin{array}{l}0 \\
0\end{array}$ & $\begin{array}{l}0 \\
0 \\
0\end{array}$ & 53 & 0 \\
\hline 10. A.S. & S. albus & RHD, MR, MS & $\begin{array}{l}3 / 13 / 61 \\
4 / 3 / 61\end{array}$ & $\begin{array}{l}\mathbf{0} \\
\mathbf{0}\end{array}$ & $\begin{array}{r}40 \\
0\end{array}$ & $\begin{array}{l}\mathbf{0} \\
\mathbf{0}\end{array}$ & 37 & 4 \\
\hline 11. $\begin{array}{l}\text { M.C. } \\
\text { F }\end{array}$ & Salm. chol. & None & $\begin{array}{l}8 / 8 / 60 \\
9 / 20 / 60\end{array}$ & $\begin{array}{l}\mathbf{0} \\
\mathbf{0}\end{array}$ & $\mathbf{0}$ & $\begin{array}{l}\mathbf{0} \\
\mathbf{0}\end{array}$ & & \\
\hline $\begin{array}{l}\text { 12. A.S. } \\
\text { M } 57\end{array}$ & S. aureus & RHD, MR & $\begin{array}{l}3 / 29 / 61 \\
6 / 6 / 61\end{array}$ & $\begin{array}{r}2,560 \\
0\end{array}$ & $\mathbf{0}$ & $\begin{array}{l}2+ \\
0\end{array}$ & 89 & 2 \\
\hline 13. $\begin{array}{l}\mathrm{P} . \mathrm{U} \\
\mathrm{M} 45\end{array}$ & $\alpha$-strep. & RHD, AS, AI & $\begin{array}{l}1 / 14 / 61 \\
1 / 24 / 61\end{array}$ & $\begin{array}{l}160 \\
160\end{array}$ & $\begin{array}{l}\mathbf{0} \\
\mathbf{0}\end{array}$ & $\begin{array}{l}1+ \\
0\end{array}$ & 43 & 0 \\
\hline $\begin{array}{l}\text { 14. M.A. } \\
\text { F } 21\end{array}$ & $\alpha$-strep. & $\begin{array}{l}\text { RHD, AS, AI } \\
\text { MR, MS }\end{array}$ & $4 / 9 / 61$ & 0 & 0 & 0 & & \\
\hline 15. F.C. & $\alpha$-strep. & RHD, AS, AI & $4 / 19 / 61$ & $\mathbf{0}$ & $\mathbf{0}$ & \pm & 47 & 2 \\
\hline $\begin{array}{l}\text { 16. E.N. } \\
\text { F } 50\end{array}$ & Grp. $\beta$-strep. & RHD, MR & $\begin{array}{l}1 / 14 / 61 \\
2 / 13 / 61 \\
3 / 18 / 61 \\
4 / 9 / 61\end{array}$ & $\begin{array}{l}40 \\
40\end{array}$ & $\begin{array}{l}0 \\
0\end{array}$ & $\begin{array}{l}2+ \\
0 \\
0 \\
0\end{array}$ & $\begin{array}{l}34 \\
55\end{array}$ & $\begin{array}{l}0 \\
0\end{array}$ \\
\hline 17. H.O. & Enterococ. & $\begin{array}{l}\text { RHD, AI, AS } \\
\text { MR }\end{array}$ & $\begin{array}{l}4 / 7 / 61 \\
4 / 15 / 61 \\
4 / 26 / 61 \\
5 / 20 / 61 \\
7 / 7 / 61\end{array}$ & $\begin{array}{r}160 \\
160 \\
80 \\
80\end{array}$ & $\begin{array}{r}160 \\
80 \\
320 \\
40\end{array}$ & $\begin{array}{l}2+ \\
2+ \\
\pm \\
\pm \\
0\end{array}$ & $\begin{array}{l}78 \\
53 \\
63\end{array}$ & $\begin{array}{l}4 \\
2 \\
0\end{array}$ \\
\hline 18. $\begin{array}{l}\text { P.O. } \\
\mathrm{M} 60\end{array}$ & Enterococ. & $\begin{array}{l}\text { RHD, AI } \\
\text { MR }\end{array}$ & $\begin{array}{l}4 / 7 / 61 \\
4 / 15 / 61 \\
4 / 26 / 61 \\
5 / 20 / 61\end{array}$ & $\begin{array}{r}320 \\
320 \\
0\end{array}$ & $\begin{array}{r}320 \\
80 \\
0\end{array}$ & $\begin{array}{l}1+ \\
0 \\
0 \\
0\end{array}$ & $\begin{array}{l}40 \\
35 \\
35 \\
40\end{array}$ & 4 \\
\hline
\end{tabular}

* Abbreviations : cap. precip., capillary precipitin test; RHD, rheumatic heart disease; MR, mitral regurgitation; ASHD, arteriosclerotic heart disease; AI, aortic insufficiency; AS, aortic stenosis; MS, mitral stenosis.

+ Dead. 
TABLE I-(Continued)

\begin{tabular}{|c|c|c|c|c|c|c|c|c|}
\hline \multirow{2}{*}{$\begin{array}{c}\begin{array}{c}\text { Patient } \\
\text { Sex Age }\end{array} \\
\text { 19. J.W. } †\end{array}$} & \multirow{2}{*}{$\begin{array}{l}\text { Blood culture } \\
\alpha \text {-strep. }\end{array}$} & \multirow{2}{*}{$\begin{array}{c}\begin{array}{c}\text { Type of heart } \\
\text { disease }\end{array} \\
\text { RHD, AS, MR }\end{array}$} & \multicolumn{2}{|c|}{$\begin{array}{l}\text { Latex fixation titer } \\
\text { Date }\end{array}$} & \multirow{2}{*}{$\begin{array}{c}\begin{array}{c}\text { Sheep- } \\
\text { cell } \\
\text { titer }\end{array} \\
320\end{array}$} & \multirow{2}{*}{$\begin{array}{c}\begin{array}{c}\text { Cap. } \\
\text { precip. }\end{array} \\
\begin{array}{l}4+ \\
4+\end{array}\end{array}$} & \multirow{2}{*}{$\frac{c^{\prime}}{17}$} & \multirow{2}{*}{$\frac{\text { Conglut. }}{64}$} \\
\hline & & & $\begin{array}{l}4 / 3 / 61 \\
4 / 7 / 61\end{array}$ & 40,960 & & & & \\
\hline $\begin{array}{l}\text { 20. M.F. } \\
\text { F } 16\end{array}$ & $\alpha$-strep. & RHD, MR & $\begin{array}{l}3 / 22 / 61 \\
3 / 30 / 61 \\
4 / 12 / 61 \\
4 / 28 / 61\end{array}$ & $\begin{array}{r}320 \\
40 \\
40\end{array}$ & $\begin{array}{l}0 \\
\mathbf{0} \\
\mathbf{0}\end{array}$ & $\begin{array}{l} \pm \\
\pm \\
0 \\
0\end{array}$ & 65 & 2 \\
\hline $\begin{array}{l}\text { 21. } \\
\text { M } 50\end{array}$ & $\alpha$-strep. & RHD, AS, MR & $\begin{array}{l}3 / 28 / 61 \\
4 / 4 / 61 \\
4 / 15 / 61 \\
4 / 26 / 61\end{array}$ & $\begin{array}{c}2,560 \\
640 \\
320\end{array}$ & $\begin{array}{r}320 \\
320 \\
80 \\
40\end{array}$ & $\begin{array}{l}3+ \\
3+ \\
2+ \\
2+\end{array}$ & $\begin{array}{l}30 \\
24 \\
38 \\
24\end{array}$ & $\begin{array}{l}8 \\
4 \\
4\end{array}$ \\
\hline $\begin{array}{l}\text { 22. A.H. } \\
\text { M } 31\end{array}$ & $\alpha$-strep. & RHD, AS, AI & $\begin{array}{l}2 / 7 / 61 \\
4 / 4 / 61 \\
6 / 17 / 61\end{array}$ & $\begin{array}{l}0 \\
0\end{array}$ & $\mathbf{0}$ & $\begin{array}{l}1+ \\
0 \\
0\end{array}$ & 57 & 2 \\
\hline $\begin{array}{l}\text { 23. M.S. } \\
\text { M } 13\end{array}$ & $\alpha$-strep. & $\begin{array}{l}\text { Tetral. of } \\
\text { Fallot }\end{array}$ & $\begin{array}{l}4 / 18 / 61 \\
5 / 9 / 61\end{array}$ & $\mathbf{0}$ & $\mathbf{0}$ & $\begin{array}{l}\mathbf{0} \\
\mathbf{0}\end{array}$ & 65 & 2 \\
\hline 24. J.K.† & S. aureus & None & $1 / 7 / 61$ & 0 & & 0 & 0 & 0 \\
\hline 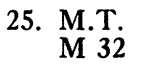 & S. aureus & RHD, MS, MR & $5 / 27 / 60$ & 0 & 0 & $\mathbf{0}$ & & \\
\hline 26. J.T. & $\begin{array}{l}\text { S. aureus } \\
\alpha \text {-strep. }\end{array}$ & RHD, MR & $3 / 2 / 60$ & 0 & 0 & 0 & & \\
\hline 27. J.D. & S. aureus & RHD, MR & $\begin{array}{l}4 / 26 / 61 \\
5 / 9 / 61\end{array}$ & $\begin{array}{l}\mathbf{0} \\
\mathbf{0}\end{array}$ & $\mathbf{0}$ & $\begin{array}{l}\mathbf{0} \\
\mathbf{0}\end{array}$ & & \\
\hline 28. ${ }_{\mathrm{F}}^{\mathrm{J}} \mathrm{T}$. & $\alpha$-strep. & RHD, MR & $5 / 9 / 60$ & 0 & $\mathbf{0}$ & $\mathbf{0}$ & & \\
\hline $\begin{array}{l}\text { 29. G.C. } \\
\text { M } 49\end{array}$ & Enterococ. & RHD, AS, MR & $6 / 10 / 60$ & 0 & 0 & \pm & & \\
\hline 30. $\underset{F}{\text { D.M. }} 5$ & $\alpha$-strep. & $\begin{array}{l}\text { Atrial sept. } \\
\text { defect }\end{array}$ & $4 / 28 / 61$ & 0 & $\mathbf{0}$ & 0 & 50 & 2 \\
\hline 31. J.A. & $\alpha$-strep. & RHD, MR, MS & $\begin{array}{l}5 / 10 / 61 \\
6 / 1 / 61 \\
6 / 28 / 61\end{array}$ & $\begin{array}{r}160 \\
80 \\
20\end{array}$ & $\begin{array}{r}160 \\
0 \\
40\end{array}$ & $\begin{array}{l}1+ \\
\pm \\
0\end{array}$ & 51 & $\mathbf{0}$ \\
\hline $\begin{array}{l}\text { 32. R.W. } \\
\text { M } 65\end{array}$ & $\alpha$-strep. & RHD, MR & $\begin{array}{l}5 / 5 / 61 \\
5 / 18 / 61 \\
5 / 30 / 61\end{array}$ & $\begin{array}{r}1,280 \\
80 \\
40\end{array}$ & $\begin{array}{l}0 \\
0\end{array}$ & $\begin{array}{l}1+ \\
1+ \\
1+\end{array}$ & 47 & $\begin{array}{l}8 \\
2 \\
0\end{array}$ \\
\hline $\begin{array}{l}\text { 33. L.I. } \\
\text { F } 40\end{array}$ & $\begin{array}{l}\text { Pasteur. } \\
\text { sept. }\end{array}$ & RHD, MR & $\begin{array}{l}1 / 10 / 61 \\
2 / 9 / 61\end{array}$ & $\mathbf{0}$ & $\mathbf{0}$ & $\begin{array}{l}\mathbf{0} \\
\mathbf{0}\end{array}$ & 47 & 2 \\
\hline 34. Q.S. & $\alpha$-strep. (?) & RHD, MR, MS & $3 / 29 / 61$ & 0 & $\mathbf{0}$ & $1+$ & 58 & 8 \\
\hline 35. E.L. & Grp. $\gamma$-strep. & RHD, MR & $6 / 15 / 61$ & 80 & $\mathbf{0}$ & $3+$ & 27 & 16 \\
\hline 36. $\begin{array}{l}\text { P.B. } \\
\text { M } 49\end{array}$ & Vibrio fetus & RHD, MR, AS & $6 / 27 / 61$ & 0 & $\mathbf{0}$ & 0 & 28 & 8 \\
\hline $\begin{array}{l}\text { 37. } \\
\text { M.B. } 56\end{array}$ & Enterococ. & RHD, MR, AS & $\begin{array}{l}6 / 14 / 61 \\
6 / 26 / 61\end{array}$ & 1,280 & 0 & $\begin{array}{l}2+ \\
2+\end{array}$ & & 8 \\
\hline $\begin{array}{l}\text { 38. F.M. } \\
\text { M } 33\end{array}$ & $\alpha$-strep. & RHD, MR, AS & $6 / 1 / 61$ & 0 & $\mathbf{0}$ & $1+$ & & 2 \\
\hline $\begin{array}{l}\text { 39. A.A. } \\
\text { M } 21\end{array}$ & $\alpha$-strep. & RHD, AS, MR & $6 / 30 / 61$ & 0 & 0 & \pm & 43 & 4 \\
\hline 40. J.S. & $\alpha$-strep. & RHD, MR & $\begin{array}{l}6 / 15 / 61 \\
6 / 30 / 61\end{array}$ & 40 & 160 & $1+$ & 62 & 8 \\
\hline 41. T.F. $\begin{array}{l}\text { M } 57 \\
\text { Th }\end{array}$ & $\begin{array}{l}\alpha \text {-strep. } \\
\text { diphth. }\end{array}$ & RHD, MR & $6 / 2 / 61$ & 640 & 40 & $3+$ & & 8 \\
\hline
\end{tabular}




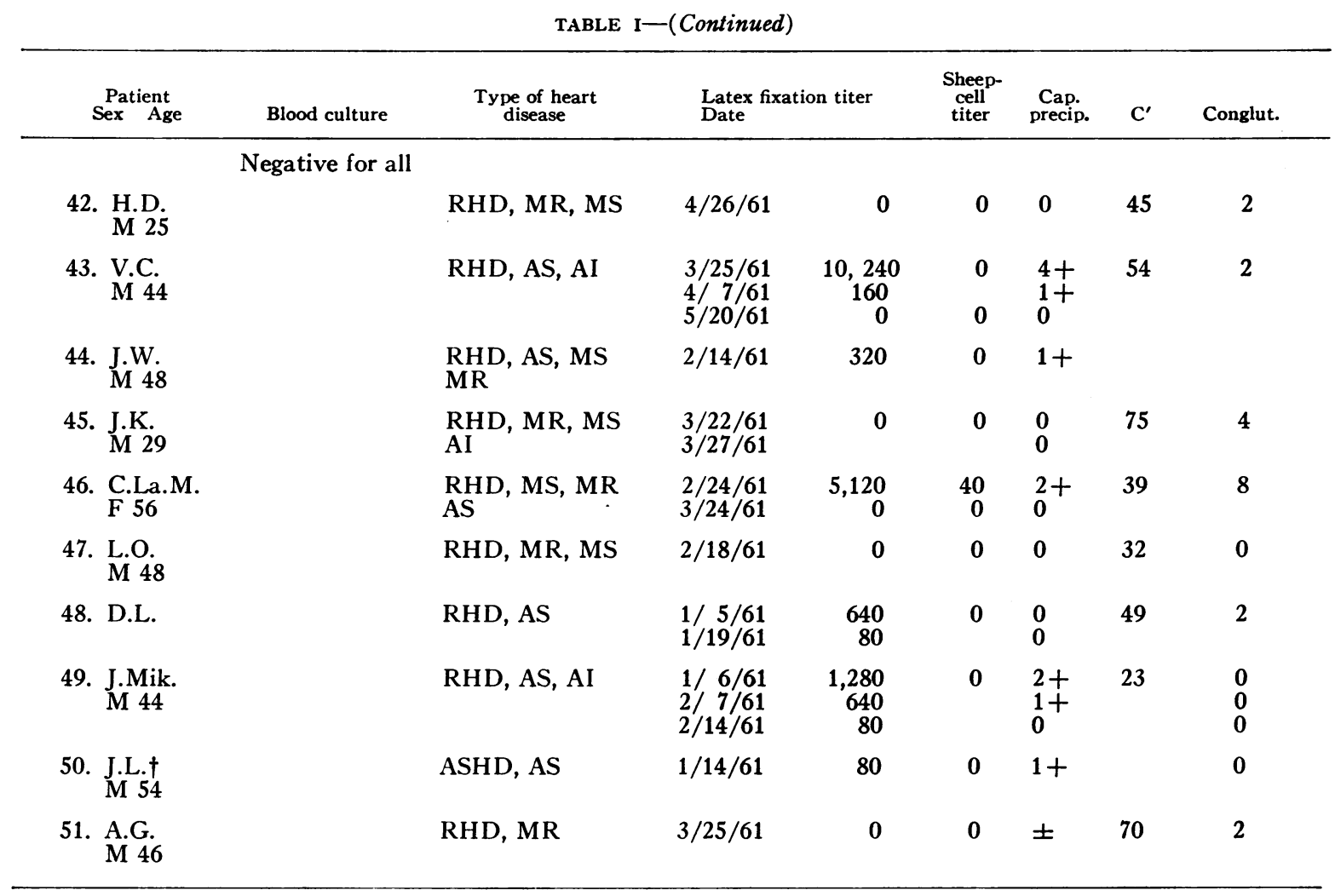

were many striking examples, however, in which the sensitized sheep cell test was negative despite extreme titers in the latex test. Many of the most actively reacting sera were found in patients with Streptococcus viridans endocarditis. Organisms producing endocarditis and no latex reactivity were Pasteurella septica, Salmonella choleraesuis, Vibrio fetus, and several strains of enterococci. Results of capillary precipitin tests in patients with subacute bacterial endocarditis roughly paralleled their latex reactivity.

We obtained some quantitation of the rheumatoid factors in the sera tested, by means of precipitin curves, using pure aggregated $\gamma$-globulin and heated serum. These curves were relatively constant and reproducible with aggregates produced from the same batch of $\gamma$-globulin, and were controlled by running aliquots of a standard serum in each set of determinations. Marked variation in amounts of precipitating material was notable among the entire group of 51 patients. Representative serial curves are shown in Figure 1. Heat-labile components accounted for only a small portion of the precipitin curves. Serum
Wo contained uniquely large amounts of rheumatoid factors. In three patients with multiple previous episodes of bacterial endocarditis no detectable elevation of rheumatoid factor occurred. This was also true in the case of two children with bacterial endocarditis, although the organism was an $\alpha$-hemolytic streptococcus.

After therapy many of the patients showed a marked reduction of rheumatoid factors, as measured by the various serological tests as well as by precipitin curves. This is indicated by Figures 2, 3, and 4, which show serial observations in three treated patients. Patient C.M. (Figure 2) showed a striking fall in all rheumatoid factor tests within 1 month after antibiotic therapy. Similar falls were noted in a number of the other patients, although in the majority the fall was somewhat less rapid. In a few no change was observed after therapy. The exact reason for this was not entirely clear, although in one there was evidence of chronic liver disease.

The subacute bacterial endocarditis sera produced a variable pattern of agglutination when tested with red cells coated with incomplete anti- 


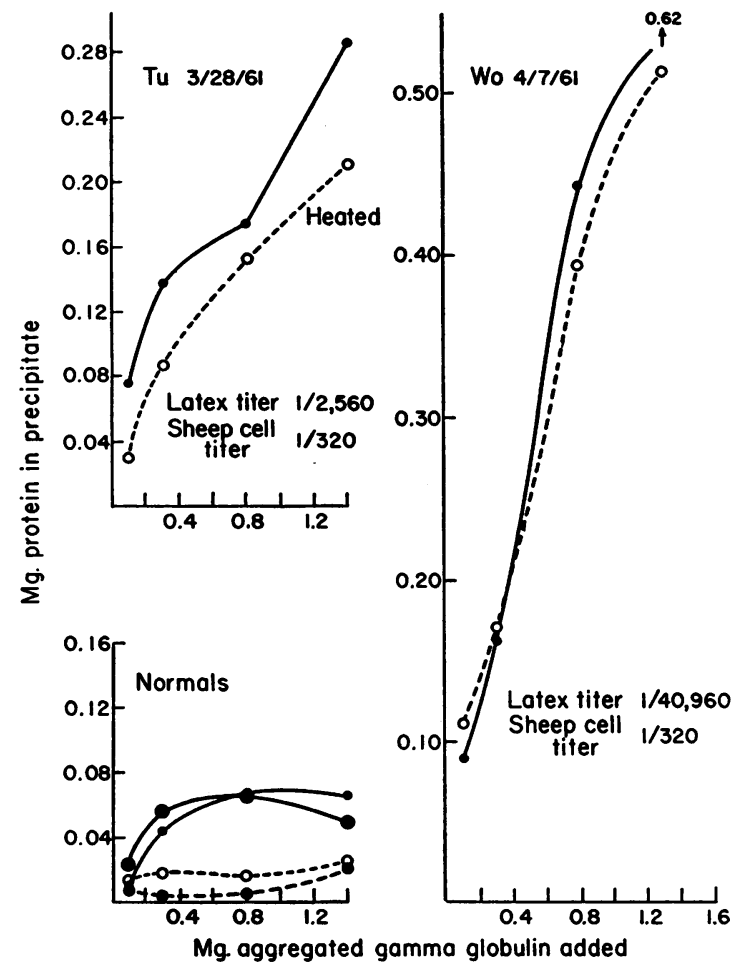

Fig. 1. Precipitin curves showing the reaction of AGGREGATED $\boldsymbol{\gamma}$-GLOBULIN WITH TWO SUBACUTE BACTERIAL ENDOCARDITIS SERA (Wo AND TU), COMPARED TO THE REACTION WITH NORMAL SERA. - Unheated serum; -- - , serum heated at $56^{\circ} \mathrm{C}$ for 30 minutes.

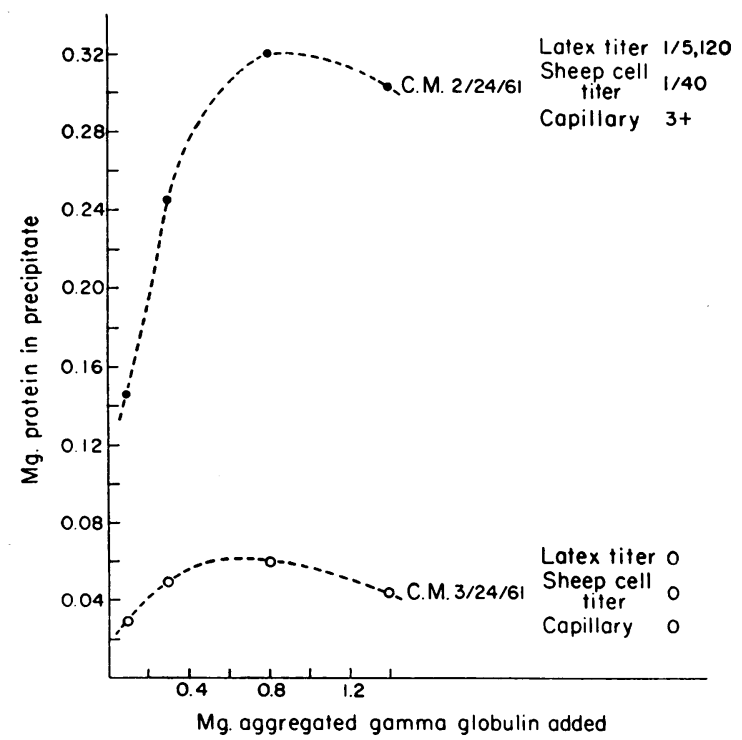

Fig. 2. Change in Precipitin Curves and other MEASUREMENTS OF RHEUMATOID FACTORS IN PATIENT C.M. AFTER TREATMENT OF THE SUBACUTE BACTERIAL ENDOCARDITIS.
$\mathrm{Rh}$ antibody coats. The strongest coats facilitating agglutination were the Murphy and Ripley anti-Rh antibody coats. Some of these results are indicated in Table II. In general the reactivity with anti-Rh coats was more restricted than in the case of rheumatoid arthritis sera. For example, coat $\mathrm{La} \mathrm{P}$. which is agglutinated by the majority of rheumatoid arthritis sera reacted significantly only with serum J. Mik.

Serum complement levels. Serum complement determinations in the majority of sera from patients with bacterial endocarditis ranged from normal to elevated levels of 50 per cent hemolytic units (normal being 34 to $45 \mathrm{U}$ per $\mathrm{ml}$ ). In eight patients, however, definite depression of serum complement was present (Figure 5). Each

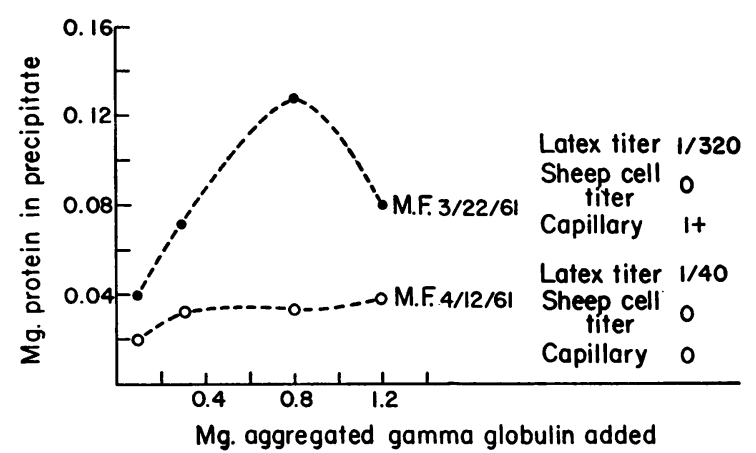

Fig. 3. Change in PRecipitin curves and other MEASUREMENTS OF RHEUMATOID FACTORS IN PATIENT M.F. AFTER TREATMENT OF THE SUBACUTE BACTERIAL ENDOCARDITIS.

of these patients with depression of complement had moderate to severe renal involvement secondary to subacute bacterial endocarditis. Two of the latter had focal embolic glomerulonephritis confirmed at autopsy. In several patients serial determinations of complement showed a return to normal as the embolic glomerulonephritis abated.

All sera in which serum complement was determined were also analyzed by immunoelectrophoresis for qualitative determination of the $\beta_{10}$ constituent of $\mathrm{C}_{3}^{\prime}(22,23)$. Fresh serum with normal complement activity was employed as control. The sera that showed depression of total serum complement activity by the 50 per cent hemolytic method likewise showed very faint lines for $\beta_{1 \mathrm{c}}$ in immunoelectrophoresis. In these low complement sera immunoelectrophoresis against 
highly specific anti- $\beta_{1 \mathrm{c}}$ antiserum confirmed the reduced levels of this component.

Conglutinin determinations. Conglutinin levels were normal or moderately elevated in most bacterial endocarditis sera. A disparity was notable with conglutinin elevation and complement depression in many of the patients who manifested renal involvement. When no focal embolic nephritis was manifest, both complement level and conglutinin titers generally fell toward normal levels as treatment progressed.

Physical studies. Serum from three patients with strong rheumatoid factor-like activity was examined by means of the Spinco model (L) ultracentrifuge and a (10 to 40 per cent sucrose) density gradient. In each case the separated $19 \mathrm{~S}$ material in the bottom fractions reacted with aggregates in capillary precipitation and in a precipitin curve. The $19 \mathrm{~S}$ material thus separated was likewise the reactive material in the anti-Rh system as a direct agglutinator. Starch block electrophoresis of highly reactive subacute bacterial endocarditis sera demonstrated the material reacting with aggregated $\gamma$-globulin in the $\gamma$-globulin fractions.

Analytical ultracentrifugation of immune precipitates of aggregated $\gamma$-globulin and bacterial endocarditis serum dissolved in glycine-saline buffer, $\mathrm{pH} 3.0$, showed a $7 \mathrm{~S}$ and a larger $19 \mathrm{~S}$ peak along with rapidly sedimenting aggregates. The pattern was very similar to that previously observed with rheumatoid arthritis sera.

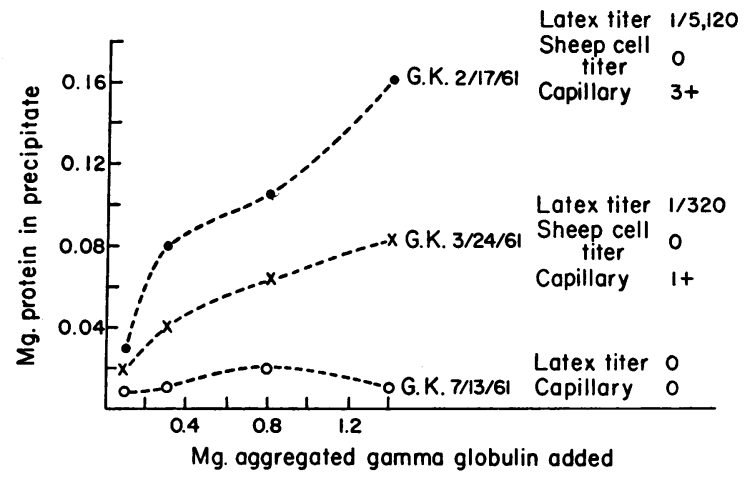

Fig. 4. Change in Precipitin CuRves and other MEASUREMENTS OF RHEUMATOID FACTORS IN PATIENT G.K. AFTER TREATMENT OF THE SUBACUTE BACTERIAL ENDOCARDITIS.

\section{DISCUSSION}

These data indicate that a rheumatoid factorlike activity may be found in the serum of many patients with subacute bacterial endocarditis. By no means organism-specific, this factor has been found in the serum of patients with $\alpha$-streptococcal, staphylococcal, and enterococcal endocarditis. It was found in highest titer in patients infected with $S$. viridans; however, this may be due to the fact that the latter organism produced endocarditis in the majority of cases studied. The results in the ten patients with negative blood cultures and presumed endocarditis are particularly interesting, since six patients showed production of rheumatoid factors, which decreased or

TABLE II

Reactions of different sera with various Rh antibody coats

\begin{tabular}{|c|c|c|c|c|c|c|c|}
\hline Patient & Murphy & Ripley & Gar. & La P. & $6023-88$ & $\mathrm{Km} *$ & Past \\
\hline 1. M.A. & ++ & ++ & 0 & 0 & 0 & 0 & + \\
\hline 2. A.J. & + & 0 & 0 & 0 & 0 & 0 & 0 \\
\hline 4. M.D. & $++t+$ & $++t$ & 0 & 0 & 0 & 0 & 0 \\
\hline 5. G.K. & 0 & 0 & 0 & 0 & 0 & 0 & 0 \\
\hline 6. J.Mc. & + & $++t$ & 0 & 0 & 0 & 0 & 0 \\
\hline 7. J.B. & 0 & 0 & 0 & 0 & 0 & 0 & 0 \\
\hline 8. A.F. & 0 & 0 . & 0 & 0 & 0 & 0 & 0 \\
\hline 11. M.C. & 0 & 0 & 0 & 0 & 0 & 0 & 0 \\
\hline 13. P.U. & 0 & $+t+$ & 0 & 0 & 0 & 0 & 0 \\
\hline 16. E.N. & $+t+$ & $+t+$ & 0 & 0 & 0 & 0 & + \\
\hline 22. A.H. & + & ++ & 0 & 0 & 0 & 0 & + \\
\hline 33. L.I. & 0 & 0 & 0 & 0 & 0 & $\mathbf{0}$ & 0 \\
\hline 48. D.L. & \pm & 0 & 0 & 0 & \pm & 0 & 0 \\
\hline 49. J.Mik. & ++ & $+t+$ & + & ++ & 0 & 0 & 0 \\
\hline 50. J.L. & 0 & \pm & 0 & 0 & 0 & 0 & 0 \\
\hline
\end{tabular}

* Rh coat useful for $\mathrm{Gm}(\mathrm{a})$ typing.

$\dagger \mathrm{Rh}$ coat useful for $\mathrm{Gm}(\mathrm{b})$ typing. 


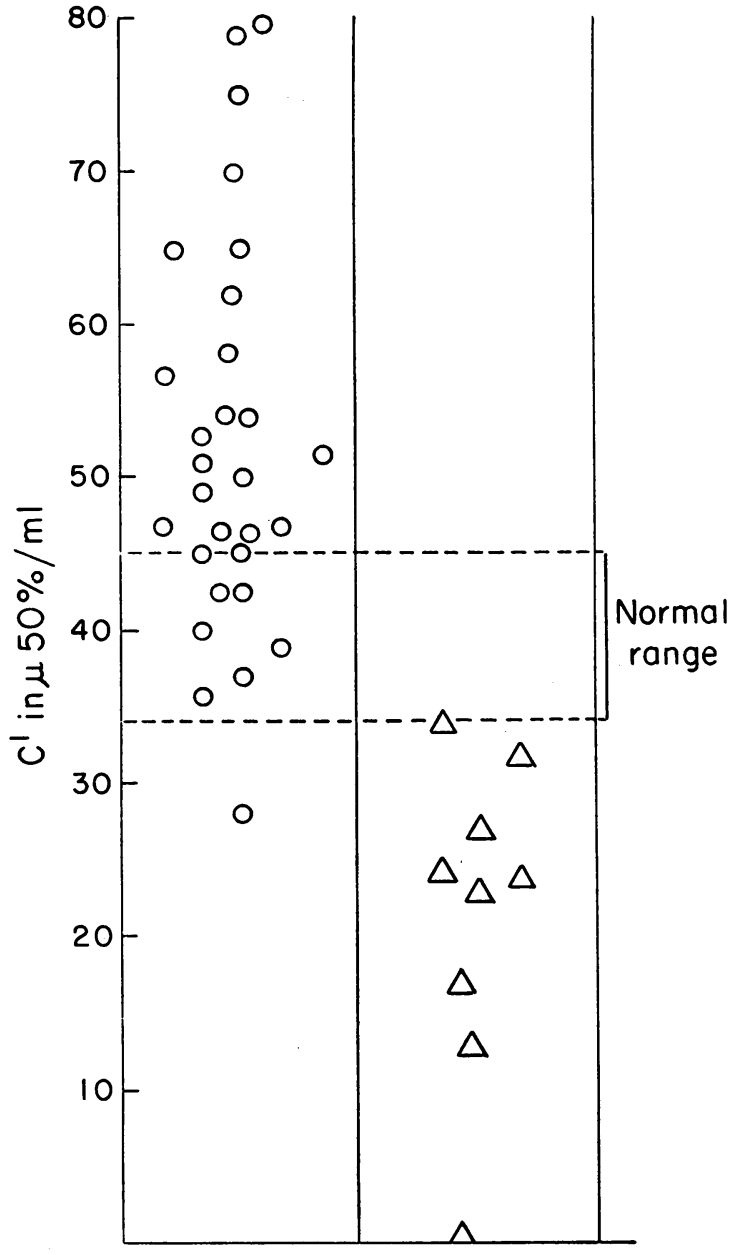

Fig. 5. Serum Complement levels in patients with SUbaCUTE bacterial endocarditis. Circles represent $\mathrm{C}^{\prime}$ in patients with uncomplicated bacterial endocarditis. Triangles represent levels in patients with focal embolic or acute diffuse nephritis.

disappeared after treatment had been instituted. It seems possible that measurement of rheumatoid factors might serve as a diagnostic aid under certain circumstances in such patients.

A number of patients $(1,5,12,32,43,49)$ showed very positive results in the latex fixation test and in the precipitin reaction with aggregated $\gamma$-globulin but were completely negative in the sensitized sheep-cell test in which rabbit $\gamma$-globulin is utilized as the coating agent. Such a pattern is very unusual in patients with rheumatoid arthritis and is more like that found in patients with sarcoid and various other diseases (14). Other patients in the group did show positive reactions in the sensitized sheep-cell test along with the other systems employing human $\gamma$-globulin so that 19 per cent were positive. In general, however, the parallelism between these reactions was less constant than in rheumatoid arthritis patients.

Just why only half of the patients showed positive results is not clear. There was no consistent difference in this group that could be ascertained. Patients 19 and 21 , with the highest titers, had probably had endocarditis for 5 to 8 months before the diagnosis was established; however, some of the negative cases also had relatively long-standing involvement. Lack of production was noted in prolonged sepsis with such organisms as $P$. septica, V. fetus, and S. choleraesuis. The great variability among patients, organisms, and treatment in the present study prevents a clear answer. Further observations concerning this point are warranted, in view of the similar finding in rheumatoid arthritis patients that certain individuals fail completely to show rheumatoid factors in their sera.

Of special interest was the finding that rapid serological reversal or profound fall occurred in many of the patients after therapy for their bacterial endocarditis. In several instances high titers fell to zero in a 2-month period. Such a change stands in striking contrast to the relative stability of such titers in rheumatoid arthritis patients over periods of many years, although some workers have reported variations (12). In sarcoid patients also, high titers appear to show little change [the two patients with the highest titers described in a previous study (14) have been followed for approximately 4 years with very little change].

The recent observation of Aho and Wager (24) that prolonged immunization with protein antigens can lead to rheumatoid factors in rabbits suggests that organisms need not be the stimulus for the production of rheumatoid factors and that those produced by injection of organisms, as in the animals reported by Abruzzo and Christian (8), resulted from the antigenic stimulus of these organisms rather than from some other infection. This may also be the case in bacterial endocarditis. In some manner the constant formation of antibodies to the organisms and their products leads to the secondary production of rheumatoid factors. A current hypothesis, held by a number 
of investigators, is that these factors represent anti-antibodies $(25,26)$ developing against new groups of the antibody molecule perhaps exposed by combination with antigen.

The present results with bacterial endocarditis suggest that, when the antigenic stimulus of organisms is cut off by therapy, the level of rheumatoid factors promptly falls. The constancy of the levels in rheumatoid arthritis patients, however, suggests a constant and long continued stimulus. This need not be of bacterial origin, although the latter deserves continued attention. But, simply because the rheumatoid factors do not directly cause the joint lesions of rheumatoid artinritis, there is no reason to think that they do not represent a clue to the disease. Further observations on these factors in experimental animals and in other diseases such as bacterial endocarditis may well prove valuable.

The eight patients with manifest focal embolic glomerulitis, or degrees of diffuse subacute glomerulonephritis, are particularly interesting, since they exhibit uniform depression of serum complement during the acute stages of their lesion. The depression of serum complement in the acute phase of the usual types of glomerulonephritis is well established $(27,28)$. It has long been known that subacute bacterial endocarditis, with organisms ranging from $S$. viridans to Haemophilus influenza or Neisseria gonorrhea, could be complicated by an acute glomerulonephritis (29$31)$. The renal lesions of subacute glomerulonephritis are generally divided into three groups: 1) focal embolic glomerulonephritis, 2) renal infarctions, and 3) acute diffuse glomerulonephritis. It is most intriguing that right-sided bacterial endocarditis, with organisms ranging from $N$. gonorrhea to the pneumococcus, has been reported, accompanied by acute diffuse glomerulonephritis (30) or focal embolic glomerulonephritis (32). The possibility is raised that such renal lesions are produced through an immune mechanism and not simply by minute bacterial emboli. In vivo fixation of complement might well explain concurrent depression of serum complement as noted in the patients studied.

Bacteria and living organisms may, under proper conditions, usurp the role of inciting antigen in the presumed immune pathogenesis of acute glomerulonephritis. The recent case report by
Marmion, Higgins, Bridges and Edwards (31) of subacute glomerulonephritis complicating rickettsial endocarditis and the previous reports following smallpox vaccination $(33,34)$ and trichinosis (35), accompanied by acute glomerulonephritis, suggest that widely differing antigens may be responsible in the pathogenesis of such lesions. In the present study various antibodies to the organisms cultured from the patients with endocarditis were measured. A wide variety of antibodies was found, including high titer antidextran antibodies with certain organisms that produced dextran. These could give rise to antigen-antibody complexes. Dixon, Feldman and Vazquez (36) have been able to produce lesions closely simulating acute and chronic glomerulonephritis by injecting simple antigen-antibody complexes. It seems that acute glomerulonephritis may well be associated with circulating antigen-antibody complexes and that such complexes, although derived from sources as divergent as $\alpha$-hemolytic streptococcus and Rickettsia burneti, may be capable of inducing the immune lesion of acute glomerulonephritis. Marks and Coombs (37) noted a definite elevation of serum immunoconglutinin titers among a group of patients with acute glomerulonephritis which is in line with the present findings. Coombs and Ingram and co-workers have postulated that immunoconglutinin is an antibody to complement fixed on antigen-antibody complexes $(19,38)$.

\section{SUM MARY}

Forty-four patients with subacute bacterial endocarditis were studied. Sera from approximately 50 per cent of these patients contained rheumatoid factor activity as confirmed by the latex fixation test, sensitized sheep-cell test, precipitin curves with aggregated $\gamma$-globulin, and reactions with incomplete anti-Rh antibody-coated red cells. The reactive factor was a $19 \mathrm{~S} \gamma$ globulin as determined by density gradient ultracentrifugation and analytical ultracentrifugation of dissolved immune precipitates. Presence of the reactive rheumatoid factor was not specifically related to any single type of infecting organism. The titers were highest, however, in patients with Streptococcus viridans endocarditis. Absence of ability to produce such a rheumatoid factor was noticed in several patients who had previously 
had multiple episodes of bacterial endocarditis, as well as in two children.

Serum complement levels were depressed in eight patients with subacute bacterial endocarditis with associated focal embolic or acute glomerulonephritis. Concurrent serial immunoconglutinin titers in most of these patients showed elevation which fell to normal as renal disease abated.

Striking falls in rheumatoid factors were observed in a number of these patients after antibacterial therapy. These changes were discussed in the light of the prolonged relative constancy of the levels in patients with rheumatoid arthritis. It is suggested that in the latter patients the rheumatoid factors result from a continued stimulus of an unknown type.

\section{REFERENCES}

1. Billings, F. Chronic infectious endocarditis. Arch. intern. Med. 1909, 4, 409.

2. Major, R. H. Clinical and bacteriological studies on endocarditis lenta. Bull. Johns Hopk. Hosp. 1912, 23, 326.

3. Kinsella, R. A. Bacteriologic studies in subacute streptococcus endocarditis. Arch. intern. Med. 1917, 19, 367.

4. Wright, H. D. The bacteriology of subacute infective endocarditis. J. Path. Bact. 1925, 28, 541.

5. Stone, G. K. Complement-fixation in streptococcal infections. Brit. J. exp. Path. 1923, 4, 318.

6. Kreidler, W. A. Bacteriologic studies in endocarditis. J. infect. Dis. 1926, 39, 186.

7. Kurtz, C. M., and White, P. D. The treatment of subacute bacterial endocarditis by transfusion from immunized donors. Report of a case. New Engl. J. Med. 1929, 200, 479.

8. Abruzzo, J. L., and Christian, C. L. Induction of a rheumatoid factor-like substance in rabbits (abstract). Arth. Rheum. 1961, 4, 103.

9. Eyquem, A., Guyot-Jeannin, N., and Podliachouk, L. Présence dans les immunsérums anti-bactériens de facteurs anti-globuliniques analogues à ceux de la polyarthrite chronique évolutive. Ann. Inst. Pasteur 1959, 96, 295.

10. Jacobson, A. S., Kammerer, W. H., Wolf, J., Epstein, W. V., and Heller, G. The hemagglutination test for rheumatoid arthritis. III. Clinical evaluation of the sheep erythrocyte agglutination (S.E.A.) test and gamma globulin (FII) tests. Amer. J. Med. 1956, 20, 490.

11. Aho, K., Kirpilä, J., and Wager, O. The persistence of the agglutination activating factor (AAF) in the circulation. A nine-year study of twenty-seven patients. Ann. Med. exp. Fenn. 1959, 37, 377.
12. De Forest, G. K., Mucci, M. B., and Boisvert, P. L. The clinical behavior of the hemagglutination test for rheumatoid arthritis. Amer. J. Med. 1956, 21, 897.

13. Franklin, E. C., Holman, H. R., Müller-Eberhard, H. J., and Kunkel, H. G. An unusual protein component of high molecular weight in the serum of certain patients with rheumatoid arthritis. J. exp. Med. 1957, 105, 425.

14. Kunkel, H. G., Simon, H. J., and Fudenberg, H. Observations concerning positive serologic reactions for rheumatoid factor in certain patients with sarcoidosis and other hyperglobulinemic states. Arth. Rheum. 1958, 1, 289.

15. Franklin, E. C., Kunkel, H. G., and Ward, J. R. Clinical studies of seven patients with rheumatoid arthritis and uniquely large amounts of rheumatoid factor. Arth. Rheum. 1958, 1, 400.

16. Müller-Eberhard, H. J., and Kunkel, H. G. Isolation of a thermolabile serum protein which precipitates $\boldsymbol{\gamma}$-globulin aggregates and participates in immune hemolysis. Proc. Soc. exp. Biol. (N. Y.) 1961, 106, 291.

17. Fischel, E. E., Pauli, R. H., and Lesh, J. Serological studies in rheumatic fever. II. Serum complement in the rheumatic state. J. clin. Invest. 1949, 28, 1172.

18. Mayer, M. M., Eaton, B. B., and Heidelberger, M. Spectrophotometric standardization of complement for fixation tests. J. Immunol. 1946, 53, 31.

19. Coombs, A. M., and Coombs, R. R. A. The conglutination phenomenon-IX. The production of immuno-conglutinin in rabbits. J. Hyg. (Lond.) 1953, 51, 509.

20. Kunkel, H. G., and Slater, R. J. Zone electrophoresis in a starch supporting medium. Proc. Soc. exp. Biol. (N. Y.) 1952, 80, 42.

21. Edelman, G. M., Kunkel, H. G., and Franklin, E. C. Interaction of the rheumatoid factor with antigenantibody complexes and aggregated gamma globulin. J. exp. Med. 1958, 108, 105.

22. Müller-Eberhard, H. J., Nilsson, U., and Aronsson, T. J. Isolation and characterization of two $\beta_{1-}$ glycoproteins of human serum. J. exp. Med. 1960, 111, 201.

23. Müller-Eberhard, H. J., and Nilsson, U. Relation of a $\beta_{1}$-glycoprotein of human serum to the complement system. J. exp. Med. 1960, 111, 217.

24. Aho, K., and Wager, O. Production of "anti-antibodies" in rabbits. Appearance in rabbit serum of "anti-antibodies" reacting with autogenous and isogenous antibody, following autostimulation with protein antigens. Ann. Med. exp. Fenn. 1961, 39, 79.

25. Milgrom, F., and Witebsky, E. Studies on the rheumatoid and related serum factors. I. Autoimmunization of rabbits with $\gamma$-globulin. J. Amer. med. Ass. 1960, 174, 56.

26. Kunkel, H. G. The rheumatoid factors. A.M.A. Arch. intern. Med. 1959, 104, 832. 
27. Veil, W. H., and Buchholz, B. Der Komplementschwund im Blute. Eine bedeutsame immunobiologische Reaktion beim rheumatischen Infekt und ihre Beziehung zur allgemeinen Pathologie des Rheumatismus. Klin. Wschr. 1932, 11, 2019.

28. Lange, K., Graig, F., Oberman, J., Slobody, L., Ogur, G., and Lo Castro, F. Changes in serum complement during the course and treatment of glomerulonephritis. Arch. intern. Med. 1951, 88, 433.

29. Baehr, G. Renal complications of endocarditis. Trans. Ass. Amer. Phycns 1931, 46, 87.

30. Helpern, M., and Trubek, M. Necrotizing arteritis and subacute glomerulonephritis in gonococcic endocarditis. Toxic origins of periarteritis nodosa. Arch. Path. (Chicago) 1933, 15, 35.

31. Marmion, B. P., Higgins, F. E., Bridges, J. B., and Edwards, A. T. A case of subacute Rickettsial endocarditis; with a survey of cardiac patients for this infection. Brit. med. J. 1960, 2, 1264.

32. Bain, R. C., Edwards, J. E., Scheifley, C. H., and Geraci, J. E. Right-sided bacterial endocarditis and endarteritis. A clinical and pathologic study. Amer. J. Med. 1958, 24, 98.
33. Herbut, P. A. Diffuse glomerulonephritis following revaccination for smallpox. Amer. J. Path. 1944, 20, 1011.

34. Melnotte, P., and Duret, M. Néphrite aiguë après vaccination triple associée. Soc. Méd. milit. franç. Bull. 1938, 32, 105.

35. Reimann, H. A., Price, A. H., and Herbut, P. A. Trichinosis and periarteritis nodosa. Differential diagnosis; possible relationship. J. Amer. med. Ass. 1943, 122, 274.

36. Dixon, F. J., Feldman, J. D., and Vazquez, J. J. Experimental glomerulonephritis. The pathogenesis of a laboratory model resembling the spectrum of human glomerulonephritis. J. exp. Med. 1961, 113, 899.

37. Marks, J., and Coombs, R. R. A. The conglutination phenomenon. XI. Immuno-conglutinin in human sera. J. Hyg. (Lond.) 1957, 55, 81.

38. Ingram, D. G., Barber, H., McLean, D. M., Soltys, M. A., and Coombs, R. R. A. The conglutination phenomenon. XII. Immuno-conglutinin in experimental infections of laboratory animals. Immunology 1959, 2, 268. 